\title{
Editorial Dilemmas and Problems
}

A task for a head editor of a scientific journal, such as a chief editor or an executive editor, it is not simple, it is out of the question. Since the administration and integration of the team which includes assigning the manuscript to the collaborators (editors of the field, etc.) until the final decision, as to the acceptance or the rejection of a manuscript, requires an expenditure of intellectual energy and even physical. But, what kind of responsible task does not require full dedication? As if there were no other demands, and that would be too much, nevertheless, there are particularities in each journal that need special attention for a satisfactory performance, which it is not easy. I refer to the pertinent aspects of the journal's scope and its methodological particularities. Even though there are competent editors of the field with well-defined tasks, it is a key issue for maintaining the uniformity and homogeneity at this Journal, that the "eye" of a chief editor or an executive editor has the expertise to detect in the final version of any article, one or another basic element that has gone unnoticed by other editors or those who are responsible for other constituents of a scientific text (technical adequacy of the tables, mathematical formulas, figures, etc.).

Of course, the existence of ad hoc editors, collaborators and reviewers 1,2 - by which they were chosen for their scientific competences - are fundamental for that each manuscript meets the general characteristic of the journal in terms of scientific style, ownership of the applied methods, the ability to dialogue in technical terms with the proofreaders in which this would greatly facilitate the executive editor's work.

On the other hand, the doubts in the analysis of a text at this point are much more difficult to resolve, and yet, at the end, it will emphasize one of the basic quality of any scientific journal.

However, it is important to comment, in terms of the scope, there may be more complex characteristics in several journals. Such as those journals, whose mission is broad and their multi-comprehensive scope 3,4 approaches to different aspects to achieve this mission.

In the case of the Brazilian Journal of Mother and Child Health, it is exemplary when it proposes to a "Mission of promoting scientific articles encompassing the field of maternal and child's health, the contributions that address various aspects in maternal health, woman's health and child's health, contemplating its multiple epidemiological, clinical and surgical determinants" as provided in the instructions for the authors. 5

The diversity of fields in the Journal, although it can be integrated, it represents a great difficulty in making final decisions in other to publish an article. Particularly, our Journal, publishing health studies in different fields, needs to take into account the methodological characteristics in the scientific analysis in each one of them. It is common, for example, to receive manuscripts whose exposition and analysis uses quantitative methods, while other texts use qualitative research methods. As everyone may know, these two methods are based on different assumptions and therefore it requires specific knowledge of the editors. The exchange of knowledge within the Journal is therefore, as an editor, for more competent he/she is, can he/she verify and give his/her endorsement to publish the articles from such different fields? Of course, that is when the participation of the text editor comes in, because of his/her expertise of the field.

So, we conclude that integration and personnel management, working together with these complexities, makes the editor's task require an intense dedication and even greater responsibility. 


\section{References}

1. Garcia JBS. A importância dos revisores ad hoc. [Editorial] Rev Dor. 2014; 15 (4): 243-4.

2. Padilha MI, Bruggemann OM, Costa R, Rosa LM, Silva DMGV, Vargas MA, Echevarría-Guanilo ME, Tourinho FSV, Andrade SR. O consultor ad hoc na qualificação das publicações científicas. [Editorial] Texto Contexto Enferm. 2015 ; 24 (4): $919-20$.

3. Archives of Disease in Childhood. Aim and Scope [online]. [acesso 21 mai 2018] Disponível em: https://adc.bmj.com/pages/about/

4. Cadernos de Saúde Pública. Missão [online]. [acesso 21 mai 2018] Disponível em: http://www.scielo.br/scielo.php?script=sci_serial\&pid=0102-311X\&lng=pt\&nrm=iso

5. Revista Brasileira de Saúde Materno Infantil. Missão [online]. [acesso 21 mai 2018] Disponível em: http://www1.imip.org.br/imip/revista/anexos/v18---Instrues-aos-autores---2018.pdf

\section{José Eulálio Cabral Filho 1}

1 Executive Editor of the Brazilian Journal of Mother and Child Health. Recife, PE, Brazil. 